\title{
THE ROLE OF THE COURT IN DEBT RESTRUCTURING
}

\author{
JENNIFER PAYNE*
}

This paper examines the intervention of the law, and the role of the court, in debt restructuring, both in terms of imposing constraints on creditors and in seeking to ameliorate the potential abuses that can arise from such constraints. Three potential forms of abuse are examined: the imposition of a restructuring on dissenting creditors, which introduces the potential for wealth transfers between creditors; the imposition of a moratorium while a restructuring is negotiated, which might lead to misuse of the process by managers wishing to prop up companies which are not viable, or may allow managers of a viable business to 'shake off' liabilities that it is capable of servicing; and the facilitation of rescue finance, which raises the potential for new creditors to be preferred at the expense of existing creditors. It is argued that the court's role in protecting creditors from these three forms of potential abuse is vital, although the nature of that role differs according to the form of abuse. Recent debt restructuring reform proposals in both the UK and the EU, which adopt quite different approaches to the role of the court in this process, are examined in the light of this discussion.

Key words: debt restructuring, minority oppression, moratorium, rescue finance, schemes of arrangement

\section{INTRODUCTION}

Where companies are in financial distress, trading out of their difficulties or a disposal of the assets or the business are likely to be preferable to liquidation, at least where the underlying business is sound and the company is merely financially, as opposed to economically, distressed. ${ }^{1}$ A sale of the business to a new owner in an auction process will not always be possible or desirable, however, especially in times of financial crisis, where markets are illiquid, leading to a loss of value if assets are sold at 'fire sale’ prices or, worse, if sales can only occur on a break-up basis. ${ }^{2}$ In such circumstances, a restructuring of the company's debts can allow the company, liberated

\footnotetext{
*Professor of Corporate Finance Law, University of Oxford and Fellow of Merton College, Oxford.

1 For a discussion of the distinction between financial and economic distress see D.G. Baird, "Bankruptcy’s Uncontested Axioms” (1998) 108 Yale Law Journal 573.

2 See, e.g., A. Shleifer and R. Vishny, "Liquidation Values and Debt Capacity: A Market Equilibrium Approach" (1992) 42 Journal of Finance 1343. There may also be other reasons why sales will not be possible, such as where the transfer of crucial assets to a new entity is not feasible. Outside these scenarios, sales can have some advantages over restructuring as they avoid the need for potentially costly bargaining between the company and its stakeholders.
} 
from its debt burden, to return to its business activities. A debt restructuring can be beneficial for companies, who need to be able to reshape their capital structures if they are no longer fit for purpose. It can also be beneficial for creditors and other stakeholders in the company, if they allow a company to continue and flourish rather than fail. It is not a coincidence that in the post-crisis period there has been a focus in both the EU and the UK on reforming the law in order to promote more effective restructuring options for distressed but viable companies, and it is this form of corporate rescue that will be the focus of this paper.

There are risks attached to restructuring, however, with the possibility of abuse and oppression of some parties by others during the process of restructuring. This raises the question whether and to what extent the law should be involved. There are different approaches to this issue. The 2016 EU draft Directive regarding restructuring processes, and the EU Recommendation on which it is based, both aim to minimise court involvement. ${ }^{3}$ The English debt restructuring options include some with minimal court involvement, such as Company Voluntary Arrangements (CVAs), and others with a significant role for the courts, most notably schemes of arrangement. In the US, Chapter 11 of the Bankruptcy Code relies heavily on the role of the court. The 2016 debt restructuring reform proposals of the UK Insolvency Service envisage a number of changes, but, if introduced, they will undoubtedly involve an increased role for the court in order to provide protection against the additional constraints on creditors' rights that are proposed. ${ }^{4}$

There are three different issues that raise concerns for creditors in a debt restructuring that will be discussed in this paper. The first is the imposition of a restructuring on dissenting creditors, which introduces the potential for abuse of the dissenting minority, and, in particular, for wealth transfers between creditors. Second is the imposition of a moratorium while a restructuring is negotiated, which might lead to misuse of the process by managers wishing to prop up companies that are not viable, or may allow managers of a viable business to 'shake off' liabilities that it is

\footnotetext{
${ }^{3}$ Proposal for a Directive of the European Parliament and of the Council on preventive restructuring frameworks, second chance and measures designed to increase the efficiency of restructuring, insolvency and discharge procedures and amending Directive 2012/30/EU, COM(2016) 723 final, 22 November 2016 ('Draft Directive'), recital 18 and Art 4(3); European Commission, Recommendation of 12 March 2014 on a new approach to business failure and insolvency, C (2014) 1500 final ('Restructuring Recommendation'), Recommendation no. 8.

${ }^{4}$ Insolvency Service, A Review of the Corporate Insolvency Framework: a consultation on options for reform, May 2016 ('Insolvency Service Consultation Paper, May 2016') and see Insolvency Service, Summary of Responses - A Review of the Corporate Insolvency framework, September 2016 ('Insolvency Service Summary of Responses, September 2016').
} 
capable of servicing. ${ }^{5}$ Third, the introduction of provisions designed to encourage the financing of financially distressed companies (termed here 'rescue finance'), ${ }^{6}$ particularly those that prefer the providers of new finance to existing creditors, raises concerns for the existing creditors regarding the level of their protection. The role of the court regarding oversight of these constraints on creditors' rights requires careful thought. This oversight is already well developed in the UK in relation to the first issue, particularly where the restructuring takes place by way of a scheme of arrangement. However, the English court has relatively little role to play in the second and third issues because these provisions have not been significantly developed in the UK to date. This may be set to change. The Insolvency Service's reform proposals will, if implemented, make significant changes to all three areas, expanding the extent to which debt restructuring proposals can be imposed on dissenting creditors, widening and expanding the reach of the moratorium, and introducing provisions encouraging rescue financing. The current role of the English court is key to protecting creditors in a restructuring, and if these reform proposals go ahead, the court's role will need to be further developed to deal with the additional constraints on creditors' rights that these changes will entail. There are, however, reasons to doubt whether the law's intervention in all these areas should be welcomed. This is not merely a matter of policy. Even if the law's intervention is successful in other jurisdictions, such as the US, different institutional arrangements and legal frameworks in the UK may mean that the transposition of such provisions should be resisted.

\section{WHY IS COURT INTERVENTION NEEDED IN DEBT RESTRUCTURING?}

Although there are many advantages to debt restructuring through contractual means, the law's intervention may be needed to deal with difficulties that can arise, particularly where creditors seek to disrupt the restructuring by exercising hold up rights or by seeking to enforce their claims in this period. The law's intervention may therefore be needed to promote an agreement between the parties, although such involvement may then introduce difficulties of its own.

\footnotetext{
${ }^{5}$ S. Paterson, 'Rethinking the role of the law of corporate distress in the twenty-first century', LSE Law, Society and Economy Working papers 27/2014, 16.

${ }^{6}$ This is the term adopted by the UK Insolvency Service (see, e.g., Insolvency Service Consultation Paper, May 2016, note 4 above, part 10), but other terms are also used to describe this form of financing. The European Commission uses the terms 'interim financing' and 'new financing', and in the US the terms 'debtor-in-possession' (DIP) financing or post-petition financing are used.
} 
Financial restructuring is at its heart a private matter between the parties, who need to renegotiate an agreement that no longer reflects the risks against which they agreed terms. This can be beneficial to the parties, and also to the company, particularly where the company is financially distressed and the restructuring enables the company, or at least its business, to continue, unburdened by the crippling debt that had previously hung over it. Courts do not need to be involved in debt restructuring. Indeed, until relatively recently in the UK, the law played little or no role in facilitating restructuring. Instead, stakeholders bargained for the reorganisation that they wanted via a contractual workout. Creditors can agree ex ante on a procedure to enable a prescribed majority of creditors to bind others to any reorganisation of a company's debt, but if no such procedure is in place any change in the scope or terms of the debtor's liabilities will require the consent of all creditors whose claims are to be affected.

Given this inherent feature of contractual workouts, they operate best when the lenders comprise a small group of like-minded individuals or organisations. It is easy for a contractual workout to be disrupted by the actions of one or more creditors, even, potentially, a single creditor holding a very small amount of the company’s debt. This can be done either through the creditor refusing its consent, in order to extract additional value from the company (the exercise of hold up rights), or by the creditor seeking to enforce its debt while the restructuring is being negotiated, and potentially petitioning for the company to be wound up if the debt remains unpaid. These forms of behaviour can allow individual creditors to delay or even prevent the successful agreement of a contractual workout. This may well be value destructive for the company concerned, and may have an effect on the availability and cost of capital for a company ex ante. Furthermore, a process of prolonged informal negotiation, while the debtor seeks to satisfy the requirements of all creditors, can be disadvantageous, and may be completely impractical if the debtor is facing an acute liquidity crisis. ${ }^{7}$

The law can assist with these difficulties, and indeed the State has an inherent interest in facilitating an agreement between the parties that they are unable to reach amongst themselves, in order to promote economic growth. There are three mechanisms that may be utilised to promote an agreement, namely enabling the restructuring to be imposed on dissenting creditors, imposing

\footnotetext{
${ }^{7}$ S. Chatterjee, U.S. Dhillon, and G.G. Ramirez, "Resolution of Financial Distress: Debt Restructurings” (1996) 25 Financial Management 5.
} 
some form of moratorium, and facilitating rescue finance. These mechanisms are introduced here and will be discussed at more length in sections IV-VI.

First, to deal with the hold out problem, the law can put in place some mechanism by which dissenting creditors can be bound to the restructuring plan. This mechanism could be structured in various ways. For instance, it might involve the restructuring being imposed only on dissenting creditors of a particular class if the majority of that class consents, or it might allow the restructuring to be imposed on whole classes of dissenting creditors or shareholders in some circumstances.

Second, to deal with the possibility of one or more creditors petitioning for a winding up, or otherwise seeking to assert their contractual rights against the company during the period of negotiation, a stay can be put in place. The need for creditors to be constrained from such action is well understood in the context of insolvency law, as a means of keeping the business and assets together so that they can be sold for the highest possible price. ${ }^{8}$ In the same way, a stay can be beneficial as a means of providing a breathing space for the company within which to reach an arrangement with its creditors and to keep the business and assets together long enough for a reorganisation to be effected. At its simplest this might merely prevent the creditor from asserting its debt claim against the company for the period of negotiation. It is likely to be more valuable, however, if the stay also prevents the initiation of insolvency proceedings and other legal process, given the impact of the commencement of such proceedings on the position of managers, on counterparties, and on the company's goodwill. The stay could even be extended further, to include a constraint on the ability of the creditor to terminate its contract with the company in this period.

Third, the law can facilitate the provision of new finance, both to keep the "lights on" for a period in order to enable the debtor to negotiate with its creditors and to enable the restructuring agreed between the parties to be implemented. The availability of both these forms of financing is generally a key aspect of effective corporate restructuring, allowing the continued operation of the business of the debtor or the preservation of the value of the assets of the estate. ${ }^{9}$ There are a number of different mechanisms that the law can utilise in order to encourage rescue finance, ${ }^{10}$

\footnotetext{
${ }^{8}$ See, e.g., T. Jackson, "Bankruptcy, Non-bankruptcy Entitlements, and the Creditors' bargain” (1982) 91 Yale Law Journal 857; T.H. Jackson and R.E. Scott, "On the Nature of bankruptcy: An Essay on Bankruptcy Sharing and the Creditors’ Bargain” (1989) 75 Virginia Law Review 155.

${ }^{9}$ See UNCITRAL Legislative Guide on Insolvency Law, Parts One and Two (2004) recommendation 63.

${ }^{10}$ See J. Payne and J. Sarra, ‘Tripping the Light Fantastic: A comparative analysis of the European Commission's proposals for new and interim financing of insolvent businesses' part 2 (forthcoming).
} 
including providing protection from such financing being subsequently declared void, voidable or unenforceable. ${ }^{11}$ One of the most powerful mechanisms available to encourage such finance is to give it priority over existing creditors' claims so as to overcome the debt overhang problem that can otherwise act as a deterrent to the extension of working capital to the company. Unsurprisingly, this is also the mechanism that offers the greatest threat to existing creditors' rights. This is, again, a matter that the parties can arrange contractually between themselves, without the law's intervention, by way of contractual subordination. ${ }^{12}$ Such an arrangement may, however, be subject to delays while negotiations occur, and to the use of hold up rights to extract value. Alternatively, markets can formulate their own solutions to these issues and, indeed in the UK, despite a lack of specific statutory provisions relating to this issue, existing creditors tend to provide additional funding where the company is judged to be viable. ${ }^{13}$ Nevertheless, there may be circumstances in which the intervention of the law can be, potentially, beneficial, such as where no market for such financing has developed.

It is notable that the US Chapter 11 procedure, sometimes regarded as the gold standard of debt restructuring mechanisms, contains all three of these features. Moreover, the 2016 European Commission Proposal for a Directive dealing with restructuring sets out minimum standards for the frameworks which Member States should have in place to enable to efficient restructuring of viable companies and these three features are at the heart of those proposals. By contrast, this package is noticeably absent from English law at present. ${ }^{14}$ The lack of a single mechanism offering the benefits of all three of these features, akin to US Chapter 11, has not gone unnoticed. The 2016 proposals of the Insolvency Service regarding restructuring mechanisms recommended the introduction of precisely these three devices into English law. ${ }^{15}$

\section{THE NEED TO PROTECT CREDITORS}

Once the law steps in to provide one or more of these features, this raises the possibility of abuse or misuse of the restructuring regime to the detriment of certain constituencies. Different forms of

\footnotetext{
${ }^{11}$ See, e.g., Draft Directive, note 3 above, Arts. 16-17.

${ }^{12}$ See Re Maxwell Communications Corporation plc (No. 2) [1994] 1 All E.R. 737.

${ }^{13}$ See part VI.

${ }^{14}$ For discussion see J. Payne, "Debt restructuring in English Law: Lessons from the US and the need for reform" (2014) 130 L.Q.R. 282.

${ }^{15}$ See note 4 above.
} 
abuse potentially arise in response to the different constraints on creditors' rights that the law can impose.

\section{A. Potential abuse}

\section{The imposition of the restructuring on dissenting creditors}

The ability of the restructuring to be imposed on a dissenting group leads to the possibility of abuse of that group by the majority, and of wealth transfers between creditors as a result of the restructuring process.

A wealth transfer will not arise merely because creditors dissent. There are mechanisms that can be put in place in order to protect dissenting creditors, and if these operate properly then wealth transfers should not occur. For example, in schemes of arrangement there are two protections for dissenting creditors: the fact that creditors meet in classes of those holding the same rights (and all classes must agree to the restructuring) and the oversight of the court to ensure, inter alia, that the classes are correctly constituted. As long as this occurs, then there should not be wealth transfers from dissenting to assenting creditors since all those within the same class will get the same deal. However, once it becomes possible for a restructuring to be imposed on whole classes of dissenting creditors, the opportunity for wealth transfers from the dissenting creditors to the assenting creditors arises. Take a simple scenario of a heavily indebted company which is viable but financially distressed. The senior creditors may decide to restructure the company's capital structure, perhaps by writing off the claims of the junior creditors, or by transferring the business of the company into a new entity and exchanging their debt claims for equity in the new company, leaving behind both the junior creditors and the equity holders in the old company. In such a situation, wealth transfers from the (dissenting) junior creditors to the senior creditors are possible, and likely. While a cramdown of whole classes is not possible using a scheme alone, such an outcome can be de facto achieved using a scheme combined with administration, as occurred in Re Bluebrook Ltd. ${ }^{16}$

The facts of this case illustrate the potential for wealth transfers to occur. Bluebrook Ltd. and two of its indirect subsidiaries were balance sheet insolvent. Rather than go into liquidation three schemes of arrangement were devised between the companies and the senior lenders.

16 [2009] EWHC 2114 (Ch), [2010] 1 B.C.L.C. 338. 
Effectively the business of the group would be transferred to a new corporate structure using a prepack administration, and the senior lenders would substitute their debt for shares in the restructured group. This meant that the business of the group could continue, unencumbered by its debt burden. This would be beneficial for the senior lenders: as equity holders in the new structure they would benefit if the company flourished as planned. However, the junior lenders and the shareholders would be left behind in companies whose assets had all been transferred to the new group, and cut off from the possibility of participating in any future growth in the business. On the one hand, this restructuring may be regarded as enabling the rescue of a group that would otherwise fail, but at the same time this might be regarded as an inappropriate wealth transfer from the junior creditors to the senior lenders. The junior lenders certainly claimed it was the latter: they sought the court's involvement, to protect them from this perceived abuse. ${ }^{17}$

\section{The imposition of a stay}

There is the potential for a stay to be (mis)used by managers in circumstances where the business is not viable, and the restructuring is being used as a way for the managers to postpone the inevitable, dissipating assets during the period of the stay that would otherwise be available for creditors. An alternative concern is that managers of a viable business, in alignment with the senior creditors, may use the restructuring to 'shake off' liabilities which it is capable of meeting, i.e., the restructuring might potentially be used as a means of allowing unscrupulous managers and senior lenders to benefit themselves at the expense of others. This might be as a result of writing off some or all of the existing claims against the company, or alternatively excluding or diminishing equity claims, including those with rights to convert their claims into equity, from a future stake in the "upside” of a successful company.

\section{The facilitation of rescue finance}

There are a number of mechanisms that might be introduced to facilitate rescue financing, and some pose relatively few creditor protection concerns, such as the provisions in the European Commission's 2016 draft Directive that aim to prevent such financing being declared "void, voidable or unenforceable” if the company subsequently goes into liquidation. ${ }^{18}$ These largely

\footnotetext{
${ }^{17}$ For discussion of how the court responds to this scenario see section IV.B.

${ }^{18}$ Ibid., Art. 16(3). This is subject to fraud or bad faith being involved.
} 
replicate the existing insolvency law provisions in many Member States, which seek to protect beneficial transactions from being called into question in a subsequent insolvency where creditors provide new value, and so adds little or no additional danger to existing creditors. ${ }^{19}$ However, other mechanisms do raise concerns. ${ }^{20}$ One particularly acute threat to existing creditors arises from the risk of disruption in the priority of their claims. Creditors providing rescue finance are likely to want assurance that they will be repaid. If there are unencumbered assets available, they can take security over them, but often this will not be possible. Most likely, their desire for security will need to be at the expense of existing secured creditors, i.e., the security of existing creditors will need to be overridden. Rescue financing therefore raises the issue of how the rights of the existing secured creditors are to be balanced against the need for the company to secure adequate working capital during the period of restructuring.

\section{B. The law's response}

Just as the law can solve the difficulties that arise in a contractual workout scenario by providing these features, it can also act to ameliorate the difficulties to which these mechanisms can give rise. There are a number of tools that the law can utilise in this regard, which are not mutually exclusive. The first is to place limits on the extent of this intervention. So, for example, the law might provide that any stay should generally only operate for a certain, relatively short, space of time, in order to limit the ability of managers to misuse this tool by keeping a non-viable business in existence. Second, the law can set out the process to be followed, and this process can include measures intended to deter abuse, such as a requirement that creditors should meet in classes of those with similar rights when deciding whether the approve the restructuring plan. Third, the law can establish some external party with oversight of the restructuring in order to deal with concerns about abuse and oppression. The courts are an obvious candidate for this role, but other possibilities exist, such as insolvency practitioners, who might operate either instead of or alongside the courts.

\footnotetext{
${ }^{19}$ For further discussion see J. Payne and J. Sarra, "Tripping the Light Fantastic: A comparative analysis of the European Commission's proposals for new and interim financing of insolvent businesses” (forthcoming) part 3. ${ }^{20}$ Ibid.
} 
In insolvency procedures, such as administration, it is an insolvency practitioner, rather than the court, that is central to the process. The insolvency practitioner occupies a very particular role in such circumstances, displacing the managers of the company and taking over the operation of the business. In restructuring, by contrast, there can be good reasons to leave the directors in charge of the company while the restructuring takes place, at least where the company's difficulties are not a consequence of their wrongdoing or incompetence. In particular, directors may be expected to know the company well, and have good relationships with existing creditors that will be useful in the negotiations. In addition, leaving the directors in charge incentivises them to commence a restructuring at an earlier stage and thus potentially increases the chance of success. In a restructuring, a third party is needed not to displace the directors, but to have oversight of the process of the restructuring in order to ensure that abuse and oppression are avoided. The question arises whether a court or an insolvency practitioner is best suited to this role. ${ }^{21}$

There are some disadvantages to using courts to perform this oversight role. Use of a judge as an arbiter in such matters is expensive and potentially time-consuming, and the expertise of the court may be problematic in jurisdictions which lack a level of specialisation within the judiciary. Insolvency practitioners can potentially solve these issues. However, a major concern with the use of insolvency practitioners is the possibility of conflicts of interest. ${ }^{22}$ It is crucial that all participants in the restructuring process have confidence that the external overseer is unbiased. Much will depend on who has control of the appointment decision. In other contexts, we see that the senior lenders often have effective control of the appointment of the insolvency practitioner as a consequence of complex provisions in place in the inter-creditor agreements. ${ }^{23}$ Furthermore, the directors may be aligned with the senior lenders, particularly if they are to receive equity in the restructuring. If the senior lenders have de jure or de facto control of the appointment process, then this creates concerns about the role of the insolvency practitioner. At the very least it can impact on the perception that they are unbiased. No such doubts attach to the role of the court. Although

\footnotetext{
${ }^{21}$ An alternative option would be to put in place a neutral third party (see, e.g., H. Eidenmueller and K. van Zwieten, "Restructuring the European Business Enterprise: The EU Commission Recommendation on a New Approach to Business Failure and Insolvency” (2015) 16 E.B.O.R. 625). The difficulty with such a suggestion is that this would be a very expensive option if the third party is not in a repeat game with any player.

${ }^{22}$ See, e.g., J. Armour and R.J. Mokal, "Reforming the Governance of Corporate Rescue: The Enterprise Act" (2003) 1 L.M.C.L.Q. 28, 36-37; V. Finch, "Insolvency practitioners: The Avenues of Accountability” (2012) J.B.L. 645.

${ }^{23}$ For discussion see Saltri III Ltd. v MD Mezzanine SA Sicar [2012] EWHC 3025 (Comm), [2013] 2 B.C.L.C. 217 at [25]-[26].
} 
there are some disadvantages to utilising the courts in this context, therefore, the benefits outweigh the disadvantages.

Once it is determined that the court should have a central role in overseeing this process, the nature of that role still needs to be determined. The lightest touch option would involve the creditors or other parties having the right to apply to court to challenge the restructuring in certain circumstances. The court's role would thus not be a mandatory aspect of the restructuring, and would potentially be utilised relatively rarely. ${ }^{24} \mathrm{~A}$ second option would be to make the court's role mandatory, but only at the end of the process, i.e., a decision whether to sanction the restructuring. ${ }^{25}$ The downside of this alternative is that by that stage there will be sunk costs, and the court may only have a blunt tool available to it (to sanction/not sanction), so that the only option for courts facing problems of oppression is to refuse to sanction and for companies to thus have to re-start the negotiations. A third option would be to require the court's involvement both at an early stage in the process, having oversight of the constitution and formulation of the restructuring plan, and at the sanctioning stage, much as happens in a scheme of arrangement.

The nature of the court's role will potentially differ according to the nature of the potential oppression. Three different forms of potential oppression are identified in this section, arising from an imposition of the restructuring on dissentients, misuse of a moratorium and oppression of existing creditors as a result of the existence and effect of legal measures designed to encourage rescue finance. Of these three issues, the first is one with which English courts already grapple, most obviously in schemes of arrangement where dissenting creditors, including secured and preferential creditors, can be bound where the majority of their class approve the scheme, and whole dissenting classes may be de facto crammed down where a scheme is twinned with administration. The next section will discuss whether the courts are effective at dealing with the issues of potential oppression that arise in this scenario, and whether, therefore, the courts will be in a position to deal with de jure cramdowns of whole classes if the Insolvency Service's proposals are introduced. The second and third issues have not been significant issues for the English courts to date, but this is likely to change if the Insolvency Service's proposals are effected or if the UK

\footnotetext{
${ }^{24}$ See, e.g., the right of creditors to apply to the court to challenge the CVA (Company Voluntary Arrangement) on the ground of unfair prejudice or material irregularity: Insolvency Act 1986, s. 6.

${ }^{25}$ See, e.g., Draft Directive, note 3 above, Art. 4(3), which envisages a limited role for "judicial or administrative" authorities, but acknowledges the need for oversight in order to protect minority creditors from oppression in certain situations (recital 19).
} 
is still a member of the EU at the point when the draft Directive's proposals mature to the point of requiring implementation in Member States. These issues are discussed in the following sections and it is argued that the court's intervention to ensure creditor protection is essential.

\section{THE ROLE OF THE COURT IN PREVENTING MINORITY OPPRESSION}

Where the law allows a restructuring to be imposed on dissenting stakeholders, this raises the possibility of abuse, and in particular of wealth transfers from the minority to the majority. The broadest form of such imposition in English law arises where a scheme is combined with administration, the major benefit of which is that it enables a de facto cramdown of whole classes to take place, as occurred in Re Bluebrook $L t d .{ }^{26}$ Indeed, the facts of this case illustrate the challenge for the courts, namely the need to rescue a financially distressed company that is encumbered with huge debts, but without that rescue being at the expense of the junior creditors and shareholders.

The law requires the court's involvement at two points in order for a scheme to go ahead: at the convening stage in order to ensure that, inter alia, the creditors and members are divided into the correct classes to decide on the scheme, and at the sanctioning stage. A clear role for the court to protect the minority is built into the Act: [p]arliament has recognised that it is for the court ... to hold the ring between the different interests." ${ }^{27}$ However, the legislative provisions are relatively short and much of the detail regarding the court's role is left to be determined by the courts themselves.

\section{A. The role of the court at the convening hearing}

The first opportunity for the court to protect creditors arises from the requirement for the court to order the meetings of creditors and members to consider the scheme. ${ }^{28}$ The court is not concerned with the merits of the scheme at this stage. ${ }^{29}$ Recent cases have demonstrated a willingness on the part of the courts to intervene, but their role is a relatively limited one. The court ensures that

\footnotetext{
26 [2009] EWHC 2114 (Ch), [2010] 1 B.C.L.C. 338.

${ }^{27}$ Re BTR plc [2000] 1 B.C.L.C. 740, 748 per Chadwick L.J.

${ }^{28}$ Companies Act 2006, s. 896(1).

${ }^{29}$ Re Telewest Communications plc (No.1) [2004] EWHC 924 (Ch), [2004] B.C.C. 342, at [14].
} 
creditors receive adequate notice ${ }^{30}$ and adequate information, ${ }^{31}$ in order to enable them to attend the relevant meetings and to vote on the scheme, and the court has oversight of the organisation of creditors (and shareholders, if appropriate) into the correct classes. ${ }^{32}$

There is no doubt that providing full and accurate disclosure to creditors is a valuable form of protection. It can help them to spot abuse and to determine whether to oppose the scheme. ${ }^{33}$ Recent cases have emphasised that the court is not bound to accept at face value assertions in regarding class composition or any other matter. ${ }^{34}$ Arguably, however, the predominant device that courts can utilise to protect creditors at this stage is to ensure that they are in the correct classes. Meeting in classes of like-minded creditors is an important form of protection against intra-creditor wealth transfers since although the court has discretion to sanction a scheme, it cannot sanction it unless all of the classes have approved it. ${ }^{35}$ The legislation does not set out how classes are to be determined, so this has been left to the courts to develop. ${ }^{36}$ The greater the number of classes, the more power is potentially provided to minorities. The trend in recent years, however, has been towards fewer, larger, classes, and a focus on whether the rights of the creditors/members are similar, rather than their interests. ${ }^{37}$ This approach does not deny that there may be different constituencies, with different interests, within a single broad class, but envisages that the court will take account of these issues when deciding whether to sanction the scheme, thus shifting the issue of protection towards the sanctioning hearing. On the plus side this approach provides the court with maximum flexibility at the sanctioning stage, and allows it to focus on the real merits of the scheme, rather than allowing schemes to be bogged down, or fail, on the basis of "unmeritorious, technical objections.” ${ }^{38}$ However, this flexibility comes with a risk that the rights of members and

\footnotetext{
${ }^{30}$ Adequate notice is required, but what this means in practice will vary: see Re Indah Kiat International Finance Co. $B V$ [2016] EWHC 246 (Ch), [2016] B.C.C. 418, at [29].

${ }^{31}$ See Companies Act 2006, s. 897.

${ }^{32}$ For the requirement that creditors and members meet in classes see Companies Act 2006, s. 899(1).

${ }^{33}$ Further, the courts have emphasised the need for creditors to be provided with sufficient information to decide whether to attend the convening hearing. See, e.g., Re Van Gansewinkel Groep BV [2015] EWHC 2151 (Ch), [2016] 2 B.C.L.C. 138.

${ }^{34}$ Re Indah Kiat International Finance Co. BV [2016] EWHC 246 (Ch), [2016] B.C.C. 418, at [40].

${ }^{35}$ See Companies Act 2006, s. 899(1).

${ }^{36}$ See, e.g., Sovereign Life Assurance Co. v Dodd [1892] 2 QB 573, 583. For discussion see J. Payne, Schemes of Arrangement: Theory, Structure and Operation (Cambridge, 2014), 2.3.2.

${ }^{37}$ For recent examples see, e.g., Public Joint-Stock Company Commercial Bank "Privatbank” [2015] EWHC 3299 (Ch), Re Codere Finance (UK) Ltd. [2015] EWHC 3778 (Ch), Re Indah Kiat International Finance Co. BV [2016] EWHC 246 (Ch), [2016] B.C.C. 418.

${ }^{38}$ See G. Moss, "Hawk triumphant: a vindication of the modern approach to classes in section 425 schemes” (2002) Insolvency Intelligence 41, 43.
} 
creditors might not be fully protected. In particular, courts may be reluctant to reject a scheme late in the day, especially where the alternative is said to be liquidation. In essence, whether this shift in scrutiny maintains creditor protection will depend on the level of scrutiny that the courts give to schemes at the sanctioning stage. ${ }^{39}$ Even if the level of scrutiny is appropriate, a separate concern is whether this approach increases the cost of schemes.

In considering whether creditors/members can meet as a class, one of the issues that the court will consider is the relevant comparator, which enables it to judge the similarity or dissimilarity of creditors' and members' rights. Where the company is insolvent, for example, the starting point for determining separate classes will be the rights of creditors and members on winding up. ${ }^{40}$ This tends to mean that the classes are relatively large and few. In Re Hawk Insurance Co. Ltd., ${ }^{41}$ for example, the Court of Appeal held that all of the unsecured creditors had the same rights in a winding up, namely the right to submit their claims and have them accepted or rejected, and therefore they were treated as comprising one class, despite the fact that some had vested claims and some had contingent claims. It may seem surprising that a liquidation measure is adopted in a restructuring scheme, where the rescue of the company is being attempted, since if the particular scheme in question is unsuccessful it is likely that some other form of rescue will be attempted. Accordingly, a going concern valuation might be felt to be more appropriate. This would be likely to result in a higher valuation, and therefore potentially more classes, which might help to protect creditors from wealth transfers. This is an issue that is also relevant to the issue of creditor protection at the sanctioning stage and is discussed in more detail there.

The court can therefore have a valuable role at the convening hearing, in ensuring that creditors have adequate information, and that class meetings are appropriately constituted. The threat of wealth transfer facing the junior creditors in Bluebrook cannot be tackled using the mechanisms discussed here, however. The junior creditors were not parties to the schemes in Bluebrook, so the question of whether they had sufficient information, or in which class they should participate, did not arise. The starting position in a scheme is that only those whose rights are being affected by the scheme need to be part of it, and it is common for schemes to involve a

\footnotetext{
${ }^{39}$ See the discussion in VI.B below.

${ }^{40}$ See, e.g., Re Hawk Insurance Co. Ltd. [2001] EWCA Civ 241, [2001] 2 B.C.L.C. 480. By contrast, where the company is solvent, this comparator is not likely to be appropriate: Re British Aviation Insurance Co. Ltd. [2005] EWHC 1621 (Ch), [2006] 1 B.C.L.C. 665.

${ }^{41}$ [2001] EWCA Civ 241, [2001] 2 B.C.L.C. 480, cf. the approach adopted by Arden J. at first instance: [2001] B.C.C. 57.
} 
sub-set of the creditors. In Bluebook, the junior creditors were left behind in the original group companies. Their rights against those companies were identical before and after the schemes in formal terms, and therefore their rights were unaffected by the scheme. The junior creditors argued that the transfer of the business and assets of the old group companies to the new group structure should be regarded as impacting on their position in a material sense, since the assets were transferred to the new group. Nevertheless, the judge in Bluebrook agreed that the exclusion of the junior creditors from the scheme was appropriate in these circumstances. The issue of whether the junior creditors had been treated unfairly as a result of this transfer of the business and assets to the new group companies via the schemes was a matter to be dealt with at the sanctioning hearing, where questions of fairness are decided, and third parties affected by a scheme, such as the junior creditors in Bluebrook, have the right to appear. ${ }^{42}$

Consequently, the convening stage is not toothless as a protective device for minorities, ${ }^{43}$ and the EU Commission's desire to minimise court involvement in restructuring, in particular at an early stage in the process, should be resisted. Nevertheless, the court's protective role at the convening hearing is relatively limited, and its usefulness as a mechanism to provide meaningful protection for creditors concerned about wealth transfers as a result of a cramdown across classes, is doubtful. Instead, these issues are considered at the sanctioning stage.

\section{B. The role of the court at the sanctioning hearing}

The court is concerned with two distinct issues at the sanctioning stage. The first is procedural: does the court have jurisdiction to sanction the proposed scheme? The court will wish to ensure that the statutory provisions have been complied with, so that the correct class meetings were held, and each class approved the scheme by the requisite statutory majority. ${ }^{44}$ The court will also be concerned to ensure that the scheme falls within the proper scope of Part 26 of the Companies Act 2006, so that, for instance, where the company involved in the scheme is a foreign company, the court will determine whether there is a sufficient connection between the scheme and England. ${ }^{45}$

\footnotetext{
${ }^{42}$ See, e.g., MyTravel Group plc [2004] EWCA Civ 1734, [2005] 2 B.C.L.C. 123.

${ }^{43}$ See, e.g., Indah Kiat International Finance Co. BV [2016] EWHC 246 (Ch), [2016] B.C.C. 418.

${ }^{44}$ Companies Act 2006, s. 899(1).

${ }^{45}$ See, e.g., Re Rodenstock GmbH [2011] EWHC 1104 (Ch), [2012] B.C.C. 459, discussed in J. Payne, "Cross border schemes of arrangement and forum shopping” (2013) E.B.O.R. 563.
} 
While this scrutiny is valuable, it is the second limb of the court's role at the sanctioning stage that is the focus when considering the avoidance of minority oppression via wealth transfers, namely whether the court considers it appropriate to exercise its discretion and sanction the scheme.

The court's sanctioning role is not a rubber-stamping exercise. The mere fact that the statutory requirements have been fulfilled does not mean that the court will necessarily sanction it. The fairness of the scheme is also a relevant consideration. So, for example, the court can examine whether the result of the vote might have been affected by collateral factors, such as where members or creditors have special interests, distinct from those of the class as a whole. ${ }^{46}$ These matters are particularly important given the tendency towards fewer classes, so that classes might well contain those whose rights are identical, but whose interest in the outcome of the scheme diverge considerably. These issues can be taken into account by the court to determine whether the majority fairly represented the class on a vote in a scheme meeting. Although we do not generally observe the courts failing to sanction schemes, ${ }^{47}$ this fact may underplay the role of the court. The provision of a clear steer regarding difficulties at an early stage may mean that deficiencies are corrected before sanctioning is sought or that problematic schemes do not proceed to the sanctioning hearing. ${ }^{48}$

These issues, though, do not directly address the concerns raised by the junior creditors in Bluebrook, who were not parties to the scheme at all. Such creditors can, nevertheless, attend the sanctioning hearing and assert that the scheme is unfair to them. The approach adopted by the English court is to determine whether the junior creditors (and, therefore, anyone subordinated to them, such as the shareholders) have any remaining economic interest in the company or group. If they do not, then the scheme can be sanctioned despite their objections. In general, the focus in English company law is on protecting the interests of the residual claimants at any given point in time. So, for example, directors are required to act to promote the success of the company "for the benefit of its members as a whole" 49 when the company is solvent, but must take account of the creditors' interests when the company is insolvent, or verging on insolvency. ${ }^{50}$ Where the company is insolvent, the shareholders have no economic interest remaining in the company, and therefore

\footnotetext{
${ }^{46}$ Re British Aviation Insurance Co. Ltd. [2005] EWHC 1621 (Ch), [2006] 1 B.C.L.C. 665.

${ }^{47}$ For a recent example of a court's refusal to sanction a scheme see Puma Brandenburg Ltd. $v$ Aralon Resources and Investment Company Ltd. and Nortrust Nominees Ltd. (18 May 2017, judgment 27/2017, Guernsey Court of Appeal).

${ }^{48}$ Re Indah Kiat International Finance Co. BV [2016] EWHC 246 (Ch), [2016] B.C.C. 418.

${ }^{49}$ Companies Act 2006, s.172(1).

${ }^{50}$ West Mercia Safetywear Ltd. v Dodd [1988] B.C.L.C. 250.
} 
they should not be able to block a restructuring scheme or extract value from the senior creditors as a result of this blocking power. Similarly, where subordinated creditors are clearly out of the money, they should not be able to block the scheme. In other words, the current approach of the courts is correct in discounting the dissent of those without a remaining economic interest in the company. The effectiveness of this approach, however, relies on the courts being able to discern clearly whether the creditors or members in question have a remaining economic interest, and this in turn relies on an effective mechanism for valuation.

The approach of the English courts to this issue is still in its infancy, and is rarely discussed in detail in scheme cases, the decision in Re Bluebrook being a notable exception. The starting point for the English courts is to consider the counterfactual, namely what each creditor would receive if no restructuring were agreed. ${ }^{51}$ This is necessarily a more conservative approach than considering what each creditor would receive if the restructuring were to be successful. Often, the view is taken that if the scheme does not go ahead, the company's only alternative is liquidation, and consequently a liquidation valuation is applied to the company to determine whether the junior creditors (and shareholders) have any remaining economic interest. ${ }^{52}$ An approach that uses the liquidation comparator will provide less protection for junior creditors concerned about wealth transfers as compared to a going concern valuation, which acknowledges that there are likely to be alternatives to the scheme other than liquidation in many cases, and should generally lead to a higher valuation of the company or group. ${ }^{53}$ Senior creditors have an incentive to press for a liquidation valuation, thus reducing the possibility that junior creditors will be judged to have a remaining economic interest in the business, and making it more likely that the restructuring can go ahead without their consent. Arguing that liquidation is the only alternative also effectively holds a gun to the judge's head and puts significant pressure on them to sanction the scheme. Courts need to be prepared to resist this pressure and to determine whether this rhetoric is really

\footnotetext{
${ }^{51}$ Re Marconi Corp plc [2003] EWHC 1083 (Ch).

52 A liquidation methodology was used in Re Tea Corporation [1904] 1 Ch. 12, Re Telewest Communications Plc [2004] EWHC 924 (Ch), [2004] B.C.C. 342, and in Re MyTravel Group plc [2004] EWHC 2741 (Ch), [2005] 1 W.L.R. 2365; [2004] EWCA Civ 1734, [2005] 2 B.C.L.C. 123. In Re Bluebrook Ltd. [2009] EWHC 2114 (Ch), [2010] 1 B.C.L.C. 338, Mann J. valued the company on a going concern basis, although the judge's decision on this point should be treated with care, since the liquidation valuation was not argued before the court. Moreover, the judge did not state that the going concern basis was the correct valuation methodology to be applied whenever a debt restructuring of this kind occurs, merely that it was appropriate in the case before him.

53 See M. Crystal and R. Mokal, “The Valuation of Distressed Companies - A Conceptual Framework” (2006) 3 International Corporate Rescue 63 (Part 1) and 123 (Part 2); J. Westbrook, “The Control of Wealth in Bankruptcy” (2004) 82(4) Texas Law Review 795.
} 
justified, in order to protect the interests of junior creditors and shareholders. ${ }^{54}$ In a situation where the company is only financially distressed, a going concern valuation will generally be more appropriate than a liquidation valuation. ${ }^{55}$ Where the assets have a higher value if kept together as a functioning unit than if sold off piecemeal, a going concern valuation will more accurately reflect the reality of the situation. ${ }^{56}$

Once this matter is resolved, a further issue arises in relation to valuation that can have an important effect on the court's ability to protect minorities, namely how the going concern valuation is to be determined. One option is a market price valuation of the business. This is arguably the most accurate measure of a company's worth at a given time. ${ }^{57}$ The benefit of this option is that it can be established through a properly conducted sales process and thus avoids the subjectivity inherent in the other major option, namely market valuation opinions provided by an expert valuer. Such market valuation opinions often lead to costly and lengthy valuation fights with each party hiring their own valuer to provide an opinion that supports their position. This is also messy and difficult for the courts to mediate, unlike a market testing process which provides a clear benchmark for the court. The market valuation approach has many advantages, but comes with one significant problem from the point of view of junior creditors, namely that if the market is depressed at the time of the valuation then it may be difficult to establish a genuine auction process. There is a danger that senior lenders may be able to take advantage of a temporary dip in market conditions, in order to cut out the junior creditors, as Mann J. recognised in Bluebrook. ${ }^{58}$ In the event, this was not an issue in that case, as all of the valuations Mann J. looked at fell well short of the senior debt, including where the market valuation stripped out the "alpha factor" so that the valuation was not linked to current market conditions. It is an issue for the future, however.

\section{Introducing a standalone cross-class cramdown into English law}

Combining schemes and administration, as in Bluebrook, allows a de facto cramdown of the junior creditors. There are some disadvantages in having to combine these mechanisms to achieve this

\footnotetext{
${ }^{54}$ There is some evidence that the English courts are starting to do this: Re Van Gansewinkel Groep BV [2015] EWHC 2151 (Ch), [2016] 2 B.C.L.C. 138, at [24].

${ }^{55}$ See, e.g., Crystal and Mokal, note 53 above.

${ }^{56}$ See, e.g., Westbrook, note 53 above, at p.811.

${ }^{57}$ See Baird, note 2 above, at p.136.

${ }^{58}$ Re Bluebrook Ltd. [2009] EWHC 2114 (Ch), [2010] 1 B.C.L.C. 338, at [49].
} 
end, however. In particular, this solution requires a transfer of the business of the company or group, which is costly and cumbersome, may have tax implications and can be problematic if the creditor agreements impose constraints on the ability of the company to transfer. It is notable that the Insolvency Service’s May 2016 proposals envisage a de jure cross-class cramdown option within a single mechanism. ${ }^{59}$ Such an innovation is to be welcomed, but would cement into English law a significant risk of intra-creditor wealth transfers, and would require that the issues discussed above be tackled.

The Insolvency Service's proposals envisage the court having a very similar function in relation to a de jure cramdown to that which exists in de facto cramdowns at present, namely overseeing both the organisation of creditors and members into classes and then determining whether the restructuring should be sanctioned. This is in contrast to the proposals put forward in the European Commission's draft Directive, which envisage a potential role for "judicial or administrative authorities” only at the sanctioning stage. ${ }^{60}$ The Insolvency Service's approach is preferable since, as discussed in section IV.A, the role of the court at the convening hearing can provide valuable protective for creditors.

Issues of valuation will be key to the success of these proposals. The Insolvency Service's proposals would introduce an important change to the role of the English courts, if implemented. At present the issue of valuation only arises where schemes are twinned with administration, in which case the court regards the issue of valuation as being predominantly a matter for the administrator. If the Insolvency Service's proposals for a restructuring plan are introduced, however, ${ }^{61}$ there will be no need for an administrator to be involved, and the issue of valuation will be an issue that the court will have to take into account when determining whether to sanction the scheme, even where the scheme is uncontested. The courts will, therefore, need to have robust mechanisms in place to assess this matter. This is an issue about which the Consultation Paper has relatively little to say, ${ }^{62}$ and, unfortunately, it continues to adhere to the liquidation valuation as the minimum valuation test. ${ }^{63}$

\footnotetext{
${ }^{59}$ Insolvency Service, Consultation Paper, May 2016, note 4 above, part 9.

${ }^{60}$ Draft Directive, note 3 above, Art. 10

${ }^{61}$ See section IV.C below.

${ }^{62}$ Insolvency Service, Consultation Paper, May 2016, note 4 above, paras. 9.33-9.35.

${ }^{63}$ Ibid., para 9.20, cf. draft Directive, note 3 above, Art. 13. Respondents to the consultation highlighted the problems with this approach: Insolvency Service, Summary of Responses, September 2016, note 4 above, para. 4.10.
} 
Further clarity on this issue would be valuable, perhaps by way of statutory guidance. Considering the counterfactual, namely what each creditor would receive if no restructuring were agreed, is the right approach, but there should be a movement away from a liquidation valuation towards some "next best alternative" or equivalent model, and the courts need to be prepared to challenge companies and senior lenders on this point. It is also suggested that a market valuation is the right approach, for the reasons set out above, although this needs to be utilised with sensitivity to take account of situations where the market is depressed, and to avoid senior lenders taking advantage of temporary dips in the market valuation of a company. The courts may well need assistance in valuing companies in these circumstances, and it may therefore be worthwhile introducing a mechanism whereby the court can appoint an expert to assist it in valuation issues. Above all, however, it will be important to ensure that the process of valuation is relatively swift, so that the restructuring is not slowed down, or de-railed completely, by lengthy and contentious valuation arguments.

\section{THE ROLE OF THE COURT WHERE A RESTRUCTURING MORATORIUM IS INTRODUCED}

A stay of some kind can be beneficial to a company undergoing a debt restructuring, to provide it with a breathing space within which to negotiate the reorganisation with its creditors, but the introduction of any such stay needs to be balanced with the need to protect those whose rights are being suspended. The reduction or removal of contractually bargained for rights requires justification. If the moratorium results in a rescue for a company, this will generally be a beneficial outcome for creditors, compared to liquidation. If, however, directors use the moratorium to prop up an economically distressed company and the "breathing space" simply means that the company goes into liquidation later, and with less money available for distribution, then this is clearly problematic. The court has a relatively limited role at present. No general restructuring moratorium currently exists in English law, although the Insolvency Service’s 2016 proposals recommend its introduction. ${ }^{64}$ If these proposals are adopted, the court's role will need to expand significantly.

\section{A. The role of the court at present}

\footnotetext{
${ }^{64}$ For discussion see section V.B below.
} 
Currently, a statutory stay attaches to administration, and to CVAs when these are used to restructure the debts of small companies. Of the two, the most important stay is that attaching to administration. The moratorium attached to CVAs is naturally limited by the very small size of the companies that can make use of it. ${ }^{65}$ Furthermore, no such moratorium will arise unless the terms of the CVA so provide, and Professors Walter and Frisby found that only one per cent. of those small companies that could have made use of such a moratorium actually chose to do so. ${ }^{66}$

By contrast, the statutory stay that exists in administration arises automatically and is very significant in practice. It is a moratorium on insolvency proceedings and on other legal process. A creditor can, however, apply to court for leave to assert its legal claims against the company, for example to assert its security or to repossess its goods. ${ }^{67}$ The court therefore has a role in ensuring that the statutory stay is not operated abusively. ${ }^{68}$ The onus is on the person seeking leave, and the court will balance the legitimate interests of that individual against the interests of the other creditors of the company, in determining whether to grant leave and, if so, whether to impose terms on the leave. ${ }^{69}$ The person seeking leave will generally need to demonstrate loss of some kind, direct or indirect, but this may not be sufficient for the claim to succeed if a substantially greater loss would be caused to others, such as the remainder of the creditors, which would be out of all proportion to the benefit that would be gained by the claimant. The court is therefore engaged in a difficult balancing exercise, with the protection of the legitimate interests of the individual creditor, to be weighed against the interests of the many in terms of the overall goal of the administration. ${ }^{70}$

\section{B. The development of a restructuring moratorium}

\footnotetext{
${ }^{65}$ Insolvency Act 1986, Sch. 1A paras. 2-4.

66 A. Walters and S. Frisby, "Preliminary Report to the Insolvency Service into outcomes in company voluntary arrangements” (2011) available at ssrn.com/abstract=1792402. Professor Goode’s interpretation of this study is that the small company moratorium is a “dead letter”: R Goode, Principles of Corporate Insolvency Law, $4^{\text {th }}$ edn, 410.

${ }^{67}$ Insolvency Act 1986, Sch. B1 para. 43.

${ }^{68}$ For the list of factors that the court will take into account in this exercise see Re Atlantic Computer Systems plc [1992] Ch. 505, 542-544.

${ }^{69}$ Royal Trust Bank v Buchler [1989] B.C.L.C. 130, 135.

70 See, e.g., Funding Corp Block Discounting Ltd. v Lexi Holdings plc [2008] EWHC 985 (Ch), [2008] 2 B.C.L.C. 596.
} 
Between 2009 and 2011 the Insolvency Service developed reform proposals regarding the introduction of a statutory moratorium for debt restructurings. ${ }^{71}$ Although there was initial support for these proposals, in May 2011 the Insolvency Service announced that the reform plans were being shelved: "[it] is generally felt that the existing UK insolvency framework is coping and adapting well to the challenges that the current round of restructurings are posing, and the urgency of the case for introducing a new moratorium is not fully made out."72 One explanation for this view is the development of the distressed debt market in the UK, which provides creditors with an option to exit the company without the need to enforce their debt if they no longer wish to remain invested in the company. Another explanation is that creditors can agree a standstill arrangement amongst themselves, and indeed this is common in restructuring schemes. The possibility of such an arrangement is facilitated by the fact that many schemes involve only the financial creditors; trade creditors are generally paid in full and therefore do not need to be brought into the scheme. The number of creditors that need to agree to the standstill is therefore reduced, and the financial creditors are a sophisticated group that may be expected to appreciate the benefits for creditors as a whole that flow from a successful rescue.

Changes in the credit market in recent years, however, mean that it is not always straightforward to identify all of the financial creditors, or for their views to be sufficiently aligned to guarantee a consensual arrangement. The fact that a restructuring moratorium is needed, despite the statement of the Insolvency Service in May 2011, is evidenced by recent case law in which a judge used his case management jurisdiction under the UK’s Civil Procedure Rules to stay claims brought by certain creditors while the company's creditors considered a scheme. ${ }^{73}$ Tellingly, the May 2016 Insolvency Service proposals do include a restructuring moratorium as part of the core package of measures, and a majority of respondents to the consultation paper stated that such a moratorium would promote business rescue. ${ }^{74}$

The Insolvency Service proposes a moratorium that will operate in various forms of restructuring, including consensual workouts, CVAs, administration and schemes of arrangement, and will cover both initial negotiations and the time required for creditor approval of a statutory

\footnotetext{
${ }^{71}$ Insolvency Service, Encouraging Company Rescue- A consultation, June 2009; Insolvency Service, Encouraging Company Rescue - Summary of Responses, November 2009; Insolvency Service, Proposals for a Restructuring Moratorium - A Consultation, July 2010.

72 Insolvency Service, Proposals for a Restructuring Moratorium - Summary of Responses, May 2011, 5.

73 Bluecrest Mercantile NV v Vietnam Shipbuilding Industry Group [2013] EWHC 1146 (Comm).

${ }^{74}$ Insolvency Service Summary of Responses, September 2016, note 4 above, para. 2.1.
} 
proposal. ${ }^{75}$ The effect of the proposed moratorium would be broadly the same as that which exists in administration, namely a moratorium on insolvency proceedings and on other legal process, ${ }^{76}$ but with one important extension. In contrast to the US Chapter 11 regime, ${ }^{77}$ the statutory stay which exists in the UK has not, to date, extended to a general prevention of customers and suppliers terminating their contracts with the company on the grounds of insolvency alone, although some limited inroads have been made into creditors' rights in this regard. ${ }^{78}$ The Insolvency Service's 2016 proposals recognise the value of the US approach, and expand the scope of the proposed moratorium beyond the parameters of the stay that attaches to administration, although the ambit of the proposals is more limited than Chapter $11 .{ }^{79}$ In particular, companies would have the right to designate some contracts as essential and it would then be impossible for these contracts to be terminated or varied during the moratorium. ${ }^{80}$ This proposal recognises the fact that the withdrawal of vital services can reduce the chance of a successful business rescue and that this knowledge may lead some suppliers to demand "ransom" payments at the expense of other creditors. It does, however, raise the possibility of abuse by the company, designating a wide variety of contracts as "essential" in order to prevent their termination in this period.

Unsurprisingly, given the constraints which such a moratorium will place on creditors' rights, the proposals envisage a number of protections for creditors. The court's involvement is a crucial element of this protection, but there are others too. First, there are important constraints suggested on the way in which the stay would operate. For instance, a maximum of three months is suggested. ${ }^{81}$ The intention is to provide directors with a brief respite in which to negotiate the restructuring, but for these issues not to drag on indefinitely.

Second, companies have to meet a number of eligibility and qualifying conditions in order to make use of the moratorium. One concern raised about potential misuse of this procedure is that it may be used by directors of healthy companies to 'shake off' liabilities inappropriately. This is addressed via an eligibility condition that the company is already in financial difficulty or

\footnotetext{
${ }^{75}$ Insolvency Service Consultation Paper, May 2016, note 4 above, part 7.

${ }^{76}$ Ibid., para. 7.10.

77 See 11 USC § 365(e). For discussion see Lehman Brothers Financing Inc v BNY Corporate Trustee Services Ltd 422 BR 407 (Bankr SDNY, 2011).

${ }^{78}$ See, e.g., The Insolvency (Protection of Essential Supplies) Order 2015 SI 2015 No. 989, which seeks to ensure the continuity of supply of utilities and IT goods and services to insolvent businesses.

${ }^{79}$ The European Commission's proposal also contains proposals in this regard: Draft Directive, note 3 above, Art. 7.

${ }^{80}$ See Insolvency Service Consultation Paper, May 2016, note 4 above, part 8.

${ }^{81}$ Ibid., paras. 7.35- 7.36.
} 
"imminently" will be, ${ }^{82}$ in order to prevent such restructurings being used at too early a stage. The other major concern is that directors of unviable businesses may use the breathing space to prop up a company that can never be rescued. The Insolvency Service attempts to address this via qualifying conditions, which include the company being able to show that it is likely to have sufficient funds to carry on its business during the moratorium, meeting current obligations as and when they fall due as well as any new obligations that are incurred. This is to ensure that existing creditors are no worse off as a result of the moratorium. ${ }^{83}$

Third, in order for the moratorium to commence, directors need to propose a supervisor, such as an insolvency practitioner. This appointment is intended to provide oversight of the process, alongside the role performed by the court, and to ensure creditor protection. On commencement of the moratorium, the supervisor will need to be satisfied that the company is eligible, and for the duration of the moratorium the supervisor's role will be to ensure that the qualifying conditions continue to be met, otherwise the supervisor would need to make the creditors aware of this failure, and report it to court. ${ }^{84}$

Fourth, the court has a key oversight role in the proposed process. The moratorium would only commence when the relevant documents are filed with the court, ${ }^{85}$ and creditors would have the right to apply to court to challenge the moratorium. ${ }^{86}$ The Insolvency Service proposals suggest this would only be possible in the first 28 days of the moratorium, although ideally this right would exist for the entire period of the moratorium, in order to ensure creditor protection. Where the company proposes to designate a contract as essential, this additional imposition on creditor rights requires a greater level of court oversight. Constraining creditors' ability to utilise such clauses is controversial in the UK because it is antithetical to the notion of freedom of contract, and it is notable that the Insolvency Service's 2009 restructuring moratorium proposals did not include provisions to this effect. The Insolvency Service's 2016 proposals are also narrower than their US counterparts, as not all creditors and suppliers are prevented from terminating, only those whose services are deemed essential. Further, the invalidation of such clauses is not automatic, but requires the debtor to designate the relevant contract as essential and to justify that designation in

\footnotetext{
82 Ibid., para. 7.18.

${ }^{83}$ Ibid., para. 7.22.

84 Ibid., para. 7.43.

85 Ibid., para. 7.15.

${ }^{86}$ Ibid., para. 7.25.
} 
the documents filed with court to commence the moratorium. The proposals provide the supplier with the right to challenge the designation, in which case the court would be required to approve the application. ${ }^{87}$ However, this safeguard is reduced somewhat since the burden is cast on the supplier to provide an "objective justification” why the supply should not be designated as essential. The present proposals do not offer sufficient protection to suppliers. ${ }^{88}$ Constraining creditors' rights in this way can have benefits as a means of promoting rehabilitative rescue, but the infringement of individual creditors' freedom of contract can be justified only if suitable protections are put in place. These might include assurances from the company that its future obligations in relation to any contracts that cannot be terminated will be performed in full. Any payments for damages that result from the debtor's default and for future performance under such a contract should be treated in the same way as costs in administration, namely they should be repaid first by the company as an expense of the process. ${ }^{89}$ There will also need to be carve-outs from this provision for certain financial contracts. Most developed legal systems grant certain financial contracts special protection from insolvency laws in order to provide certainty and liquidity in the marketplace and to reduce or eliminate systemic risk, ${ }^{90}$ and a similar carve-out here, in particular for funding or hedging arrangements, is needed. ${ }^{91}$

The court will have an important role to play if the Insolvency Commission’s proposals are implemented. Tellingly, the European Commission’s proposals regarding restructuring envisage an important role for a "judicial or administrative authority" in relation to the proposed stay, ${ }^{92}$ even though, in general, the proposals seek to minimise intervention by courts and administrative authorities. ${ }^{93}$ Careful oversight of these issues is required if creditor protection is to be ensured.

\section{THE ROLE OF THE COURT WHERE THE LAW FACILITATES RESCUE FINANCE}

\footnotetext{
${ }^{87}$ Insolvency Service Consultation Paper, May 2016, note 3 above, para 8.13.

${ }^{88}$ See Insolvency Service, Summary of responses, para. 3.7.

${ }^{89}$ See Insolvency Service Consultation Paper, May 2016, note 3 above, para. 7.46.

90 The special protection currently granted to financial contracts under English law may be seen in Part VII of Companies Act 1989, the Financial Markets and Services (Settlement Finality) Regulations 2001, Financial Collateral Arrangements (No. 2) Regulations.

${ }^{91}$ See, e.g., 11 USC § 365(e)(1).

92 Draft Directive, note 3 above, Art. 6.

93 Ibid., recital 18.
} 
Companies continue to require financing during the period that debt restructuring is taking place, and securing such financing can increase the chances of continued operation for the debtor's business. There is empirical evidence to support the view that rescue financing provides value to firms in the US, where provisions encouraging such financing exist. ${ }^{94}$ While there are a number of different ways in which the law can seek to advantage the creditor providing rescue finance, a recurring issue is the ranking of such finance compared to existing lenders with otherwise equal or superior claims. This features in both the UK Insolvency Service’s 2016 proposals, ${ }^{95}$ and the European Commission's draft Directive. ${ }^{96}$ It is also an important aspect of the US Chapter 11 regime. The US Bankruptcy Code specifies a number of ways in which a lender may achieve priority for money advanced to a debtor after the bankruptcy petition date, including §364(d) which allows the debtor or trustee to seek approval of financing on a priority basis, i.e., the claim can be secured by a lien equal to or senior to an existing lien, if the applicant can establish that it was unable to obtain credit otherwise, and there is "adequate protection" for pre-filing secured creditors.

The granting of super-priority of this kind is controversial, however, given the need for the rescue financier's benefit to be at the expense of the existing lenders' priority. There is no consensus globally on this issue. ${ }^{97}$ These concerns have led the European Commission to proceed cautiously, simply providing in its draft Directive that Member States "may" afford priority to the providers of new or interim financing, but are not required to do so, and leaving the details of any super-priority to Member States to determine. ${ }^{98}$

The UK Insolvency Service’s proposals are also somewhat cautious, putting forward some “possible options"99 designed to encourage rescue finance, rather than any concrete proposals. Many of these have been advanced previously. ${ }^{100}$ One suggestion is the ability to override negative

\footnotetext{
${ }^{94}$ See, e.g., S. Dahiya, K. John, M. Puri, and G. Ramirez, "Debtor-in-possession financing and bankruptcy resolution: Empirical evidence” (2003) 69 Journal of Financial Economics 259.

${ }_{95}$ Insolvency Service Consultation Paper, May 2016, note 4 above, part 10.

${ }^{96}$ Draft Directive, note 3 above, Arts. 16-17.

${ }^{97}$ See World Bank, Doing Business Report, 2017, para. 2.7.7.

${ }^{98}$ Draft Directive, note 3 above, Art. 16(2). For an analysis see J. Payne and J. Sarra, "Tripping the Light Fantastic: A comparative analysis of the European Commission's proposals for new and interim financing of insolvent businesses" (forthcoming).

${ }^{99}$ Insolvency Service Consultation Paper, May 2016, note 4 above, para. 10.15.

${ }^{100}$ See, e.g., Insolvency Service, Encouraging Company Rescue- A consultation, June 2009; Report of the Insolvency Law Review Committee, Insolvency Law and Practice (Cmnd. 8558, 1982)); Company Law Review, Modern Company Law for a Competitive Economy- Final Report, URN 01/943, 2001.
} 
pledge clauses in certain circumstances in order to enable a distressed company to grant security for new finance. ${ }^{101}$ An alternative option is the ability of the company to grant security to new lenders over company property already subject to charges, where that new security might rank as an additional but subordinate charge on the property, or possibly as a first charge on the property (where the existing holder does not object), and, further, where the assets against which the new charge is secured prove insufficient to discharge the amount owed, any shortfall would rank above preferential and floating charge holders. ${ }^{102}$

The devil with all such proposals is in the detail, something which is largely absent from the Consultation paper. In particular, while the Insolvency Service acknowledges the need to provide "robust safeguards" for existing creditors, ${ }^{103}$ little detail of this protection is provided. Any erosion of the security rights of existing lenders would need to be carefully overseen, and the courts should play a key role in this process. The US Chapter 11 provisions include a significant role for the court in ensuring that existing creditors are appropriately protected, if super-priority is provided to the grantors of rescue finance (termed debtor-in-possession ('DIP') finance in the US). The US regime provides threshold tests that the debtor must meet before utilising such financing. For example, a debtor must demonstrate that it is unable to obtain the finance without providing such priority. Furthermore, §364(d) provides that, if the company already has secured debt, to borrow funds secured by a lien equal or senior to the existing lender, the company will either need the existing lender to consent or will have to convince the Bankruptcy Court that the existing lender's lien position will be "adequately protected". The burden of proving adequate protection is on the party seeking the priority charge. In most cases, priming liens are approved where there is no objection from the pre-petition secured lender, but the court has on occasion approved a priming lien over the objections of secured lenders. ${ }^{104}$ The purpose of the requirement under $§ 364$ (d) is to protect existing lienholders from any decrease in value of their security interest. ${ }^{105}$ Adequate protection can be provided by periodic cash payments, replacement liens or other relief resulting in the "indubitable equivalent" of the secured creditor's interest. ${ }^{106}$ Alternatively, adequate

\footnotetext{
${ }^{101}$ Ibid., paras. 10.19-10.20.

${ }^{102}$ Ibid., para. 10.21.

${ }^{103}$ Ibid., para. 10.22 .

${ }^{104}$ In re Health Diagnostic Laboratory Inc. (2015) WL 4915621 (Bankr. Ct. E.D. Virginia); Credit Alliance Corp v Dunning-Ray Ins Agency Inc (In re Blumer) (1986) 66 B.R. 109, 113 (9 $9^{\text {th }}$ Cir. Bank. Appeal Panel).

${ }^{105}$ In re Sonora Desert Dairy LLC et al (2015) WL65301 (US Bankruptcy Appellate Panel $9^{\text {th }}$ Cir.); M Bank Dallas, NA v O'Connor (1987) 808 F. 2d 1393 (10 ${ }^{\text {th }}$ Cir.).

${ }^{106}$ In re Sonora Desert Dairy LLC et al, ibid.
} 
protection can be established by demonstrating that the pre-petition lienholder is over-secured with a substantial equity cushion. ${ }^{107}$ What constitutes adequate protection is a fact-based inquiry decided by the court, having regard to the specific circumstances. ${ }^{108}$ If the UK were to introduce specific statutory provisions designed to facilitate rescue financing then pre-existing lenders' rights would need to be protected. ${ }^{109}$ The US experience demonstrates the risks attendant in this area, and the important role that the court can provide in balancing the desire of the debtor for finance, and the wish of the creditor providing rescue finance for security, with the rights of existing lenders.

There is a more fundamental concern regarding these proposed super-priority measures, however, that goes beyond the shape and detail of any such provisions, to the question whether they should be introduced at all. Reform in this area will not merely be a case of copying the provisions that have been successful in other jurisdictions. The fact that the law facilitates rescue finance in the US does not mean that it should be introduced into the UK, given the different legal frameworks, the different nature of the court systems and, crucially, distinctions in prevailing business cultures and practice. Although, in contrast to the US, the UK lacks a broad and longestablished market in specialist rescue finance, and no statutory provisions presently exist in the UK which specifically relate to this issue, there is generally funding available for financially distressed companies in the UK, at least where the business is judged to be viable. Typically, new funding in administrations is provided by the existing floating charge holder, who has no need to vary its existing security, and any assets not covered by the floating charge will already be subject to fixed charges. In practice, therefore, if the business is judged to be viable, additional funding will generally be provided by existing creditors on a consensual basis or by using a scheme of arrangement. The concern is that the introduction of legislation designed to encourage rescue finance, particularly provisions that would allow the security of existing lenders to be overridden, might disrupt this market-based solution. In particular, the introduction of such provisions might dissuade some lenders from providing finance for companies in the first place. These concerns were a major factor in the negative reception respondents provided to these proposals, 73 per cent.

\footnotetext{
107 Pistole v Mellor (In re Mellor) (1984) 734 F. 2d 1396, 1400 (9 $9^{\text {th }}$ Cir.); In re Health Diagnostic Laboratory Inc. (2015) WL 4915621 (Bankr. Ct. E.D. Virginia).

${ }^{108}$ In re Sonora Desert Dairy LLC et al, (2015) WL65301 (US Bankruptcy Appellate Panel $9^{\text {th }}$ Cir.) at 11.

${ }^{109}$ See UNCITRAL Legislative Guide on Insolvency Law, Parts One and Two (2004) recommendation 63.
} 
of whom disagreed with the options put forward. ${ }^{110}$ It is to be hoped that the response to the Consultation Paper means that the Insolvency Service’s rescue finance proposals will be shelved.

\section{CONCLUSION}

The law can have an important role in facilitating successful corporate rescues by constraining creditors' rights in various ways. The law also needs to act to ameliorate the consequential creditor oppression that can arise. The court has a central role in this regard. The greatest danger facing creditors at present is that of wealth transfers. The other concerns raised by this paper, regarding any moratorium imposed during restructuring and provisions designed to promote rescue finance, raise fewer concerns for creditors at present given the underdeveloped nature of English law on these topics. The court has a role in ensuring that the procedural requirements for the restructuring are satisfied, and in particular that safeguards designed to protect creditors are met. The role goes further than this, however. The court may well be called upon to consider whether the restructuring should go forward even where the procedural requirements have been satisfied, as can occur at the sanctioning stage of schemes at present, or to mediate between the interests of an individual creditor and the interests of the creditors as a whole, for example where a creditor seeks to assert its rights despite the existence of a stay. In order to ensure adequate creditor protection, the starting point must be that, as a minimum, creditors should not be made worse off following a reorganisation than they would be if the reorganisation were not to occur. This, however, requires a difficult assessment as to what that alternative looks like, and how the company is to be valued in that eventuality, and also what "worse off" means, so, for example, whether this requirement is satisfied where a creditor's security is overridden but they are offered periodic cash payments instead. The English courts have made some progress in answering these questions, but more is needed, particularly if the Insolvency Service’s 2016 proposals are implemented.

\footnotetext{
${ }^{110}$ Insolvency Service, Summary of Responses, para. 5.2.
} 